\title{
Assessment of Thermal-induced Forest Stress: A case of Akure Forest Reserve, Ondo
} State, Nigeria

\section{*ADAMU, IS; AIGBOKHAN, OJ; AGBOR, CF; ORUNKOYI, AR; OGOLIEGBUNE, OM}

\author{
Environmental Modeling and Biometrics Department, Forestry Research Institute of Nigeria, P.M.B 5054 Jericho, Ibadan, Oyo State, \\ Nigeria \\ *Corresponding Author Email: lollysbergtally15@gmail.com; Tel: +2348060214114
}

\begin{abstract}
Forest stress or health has become a topic of serious interest to researchers in recent times. It reached a crescendo consequent upon the renewed interest in climate change's effects, resilience and mitigation. Forest stress is majorly a climate-related occurrence that can only be managed but not totally eradicated. Therefore, this study is aimed at assessing thermal induced stress in Akure forest reserve in Ondo State, Nigeria, using the instrumentality of Remote Sensing and Geographic Information System (GIS). The temperature data used for this study was extracted from Landsat 8 (OLI) imagery obtained from United States Geological Survey (USGS) database between the years 2016 and 2020. A land use land cover change detection analysis of the study area revealed that between 2016 and 2020, forest and water body decreased from 4344.59 to 2971.71 ha and 187.28 to 178.23 ha respectively while shrubs and bare land increased from 1472.13 to 2533.05 ha and 578.16 to 899.34 ha respectively. Forest stress and health of the study area was assessed using vegetation indices and land surface temperature LST). The result reveals changes in mean LST across the four lands cover types during the study period. It ranges between $22.28{ }^{\circ} \mathrm{C}$ (water body) in 2016 to $28.99{ }^{\circ} \mathrm{C}$ (bare land) in 2018. The spatial trend of Vegetation Health Index (VHI) was used to delineate the health of the forest. The study reveals that the spectral changes in the biophysical characteristics of the forest could not be solely attributed to temperature variability. Other climatic parameters and soil related variables must have contributed to notice stress in the forest reserve. However, this study has brought to the fore the robustness of geospatial technologies on the study of forest stress, health and drought.
\end{abstract}

\section{DOI: https://dx.doi.org/10.4314/jasem.v25i6.4}

Copyright: Copyright $\odot 2021$ Adamu et al. This is an open access article distributed under the Creative Commons Attribution License (CCL), which permits unrestricted use, distribution, and reproduction in any medium, provided the original work is properly cited.

Dates: Received: 20 March 2021; Revised: 27 April 2021; Accepted: 07 May 2021

Keywords: Geographic Information System, Drought, Remote sensing, Assessment, Forest stress

The factors responsible for forest stress, health and drought are very many. One of the underpinning factors is the rising of temperatures with attendant effects as it relates to severity (WMO, 2012). Though this study is not about drought severity, but the focus is forest stress which shares so many literatures with forest health and drought assessment. Occurrence of forest stress is never sudden. It is usually a slow progression lasting for a period longer than a season. Changes in weather parameters can trigger stress or drought compared to standard conditions (Adhyani et al., 2017). The severity of forest stress is dependent not only on the duration, intensity and spatial extent, but also on the demands made by human activities and vegetation on a specific region's water supply. Research has made it known that, extreme climatic events such as droughts are forecast to become more intense, more frequent, and longer lasting in arid and semi-arid regions (Stocker, et al., 2013). Dry periods lasting for years to decades have occurred many times during the last millennium over, for example, North
America, West Africa, and East Asia. These droughts were likely triggered by anomalous tropical land surface temperatures, it is also considered to be affected by conditions of low soil moisture and insufficient surface water availability (Tosunogu et al., 2016). The African continent is considered as very susceptible to forest stress and droughts due to high unevenness of rainfall. A large number of extreme droughts have been observed in the recent past which caused famines and loss of millions of lives in Africa (Masih, et al., 2014). Erratic behaviour of climate due to climate change has potentially increased its severity in different countries including Nigeria. Spectral indices such as the Normalized Difference Vegetation Index (NDVI) (Swain et al., 2011), the Vegetation Condition Index (VCI) (Kogan, 1995; Quiring and Ganesh, 2010), Normalized Difference Water Index, NDWI was used to assess vegetation stress dynamics or drought patterns. These indices have proven to be effective in monitoring the water content of vegetation. All the indices used in this study are 
indications of stress and drought conditions because they reflect the energy and water exchanges among vegetation, soil, and atmosphere, and consider the characteristics of soil moisture (Rhee et al., 2014). However, it must be stated that NDVI has been one of the most extensively used spectral index for drought monitoring over the past decades across geographical areas and vegetation types (Boschetti et al., 2013). With innovations in geospatial technologies, multispectral assessment of forest health and drought with their attendant environmental effects are becoming popular in the deployment of several vegetation indices to assess vegetation growth in recent decades (Yang et al., 2012). For lack of in-situ metrological data (temperature and rainfall), this study is relying heavily on satellite-derived land surface temperature (LST) data from Landsat 8 (OLI). Surface temperature and surface radiation are also very important in forest stress and drought assessment (Orimoloye et al., 2018b). Software applications such as ArcGIS, QGIS, Erdas Imagine and IDRISI Selva were used for this study. This study is aimed at assessing the thermal-induced forest stress in the study area using Geographic Information System (GIS) and remotely sensed data between year 2016 and 2020 .

\section{MATERIALS AND METHODS}

Study area: Akure forest reserve is located in the rainforest zone of Akure, Ondo State, Nigeria (Figure 1). It lies between latitudes $7^{\circ} 16^{\prime}$ and $7^{\circ} 18^{\prime} \mathrm{N}$ and longitudes $5^{\circ} 9^{\prime}$ and $5^{\circ} 11^{\prime} \mathrm{E}$ of the Greenwich Meridian. (Gbiri and Nathaniel 2019). Elevation ranges from $216 \mathrm{~m}$ to $504 \mathrm{~m}$ with underlying crystalline and gneiss rock formations. The dry season lasts from November to March while the wet season commences from April and ends in October with the highest rainfall records between July and August Average daily temperature ranges between $21^{\circ} \mathrm{C}$ and $29^{\circ} \mathrm{C}$ almost throughout the year (Adejoba et al., 2014). The mean annual rainfall varies from $2000 \mathrm{~mm}$ in southern area to $1500 \mathrm{~mm}$ in northern area with annual relative humidity between 80-85\% (NiMET, 2016). This study is all about spatial assessment temperature induced stress occurrence in Akure forest reserve between 2016 and 2020 using remotely sensed data. Four land use land cover classes such as forest, bare land, water body and shrubs were used for this study. Selected vegetation indices as well as LST were used in this study to investigate forest stress occurrence in the study area during the period of study.

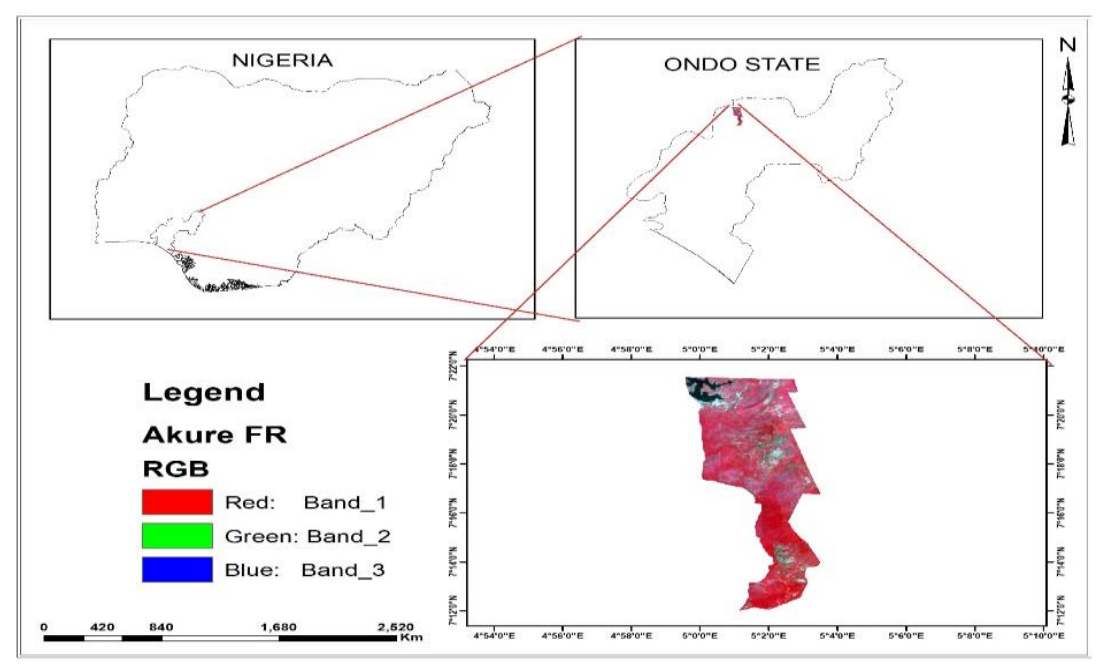

Fig 1: Study area location

Table 1: Satellite images used for the drought assessment.

\begin{tabular}{llll}
\hline Data & Year & Date of Acquisition & Path/Row \\
\hline Landsat OLI_TIRS & 2016 & $2016-01-10$ & $191 / 055$ \\
Landsat OLI_TIRS & 2018 & $2018-01-02$ & $191 / 055$ \\
Landsat OLI_TIRS & 2020 & $2016-01-15$ & $191 / 055$ \\
\hline
\end{tabular}

Image processing: Landsat images used for this study were obtained from the USGS website. The satellite images collected were in two years interval between 2016 and 2020 as shown in Table 1. Pre-processing of the Landsat images, including radiometric calibration and atmospheric correction were done using QGIS
3.16 image processing algorithm. All used Landsat images were first radiometrically calibrated using designed tool to convert image DNs into top-of atmosphere (TOA) reflectance. The images were atmospheric corrected to reflectance using DarkObject Subtraction (DOS) method (Chavez, 1996). 
The pixel TOA-reflectance was computed using equation (1):

$$
N \rho \lambda=\frac{\pi L_{\lambda} d^{2}}{E S U N_{\lambda} \sin \theta}
$$

Where; $L_{\lambda}$ is radiance in units of $\mathrm{W} /\left(\mathrm{m}^{2} . \mathrm{sr} . \mu \mathrm{m} ; d\right.$ is Earth-sun distance in astronomical units; $E S U N_{\lambda}$ is solar irradiance in $\mathrm{W} /\left(\mathrm{m}^{2} \cdot \mu m ; \theta\right.$ is sun elevation in degrees. This study used supervised classification i.e. the maximum likelihood classifier for the image classification. All the vegetation indices used in this study were calculated using equations in Table 2

Table 2: Indices used for drought assessment in Akure Forest Reserve.

\begin{tabular}{|c|c|c|c|}
\hline SN & Indices & Equations & References \\
\hline 1 & LST & $L S T=\frac{T b}{T b}$ & Orimoloye et al. $2018 \mathrm{~b}$ \\
\hline 2 & NDVI & $N D V I=\frac{\begin{array}{c}1+(\lambda \times T b(\rho) \operatorname{In} \varepsilon \\
\rho N I R-\rho R E D\end{array}}{\rho N I R+\rho R E D}$ & Yengoh et al., 2015 \\
\hline 3 & NDWI & $N D W I=\frac{\rho G R E E N-\rho N I R}{\rho G R E E N+\rho N I R}$ & $\begin{array}{l}\text { Zhang et al., 2017a,b; } \\
\text { Orimoloye et al., 2018c }\end{array}$ \\
\hline 4 & VCI & $V C I=\frac{N D V I-N D V I_{\min }}{N D V I_{\max }+N D V I_{\min }}$ & Domingo et al., 2015 \\
\hline 5 & VHI & $\begin{array}{l}V H I=\propto V C I+(1-\propto) T C I \\
* \quad \propto=0.5\end{array}$ & Domingo et al., 2015 \\
\hline
\end{tabular}

\section{RESULTS AND DISCUSSION}

The land use land cover (LULC) maps of the study area and the extracted classification statistics for 2016, 2018 and 2020 are shown in Table 3. In year 2016 the study area covered by forest was approximately 4344.57 ha $(66 \%)$, followed by shrubs with a total area of about 1472.13 ha $(22 \%)$. The area covered by bare land was 578.16 ha $(9 \%)$, while water body covered about 187.29 ha $(3 \%)$ in the same period. In 2018 , there was a reduction in forest cover from 4344.57 ha $(66 \%)$ in 2016 to 3769.38 ha $(57 \%)$ in 2018 . The results in 2020 revealed that there were changes in land use land cover types between 2018 and 2020. For instance, bare land area decreased from 1149.3ha (17\%) in 2018 to 899.34ha (14\%) in year 2020. In 2020, there were also some remarkable changes in forest cover 2971.71 ha (45\%), shrubs 2533.05ha (38\%) and water body 178.23 ha (3\%) respectively (Table 3 ).

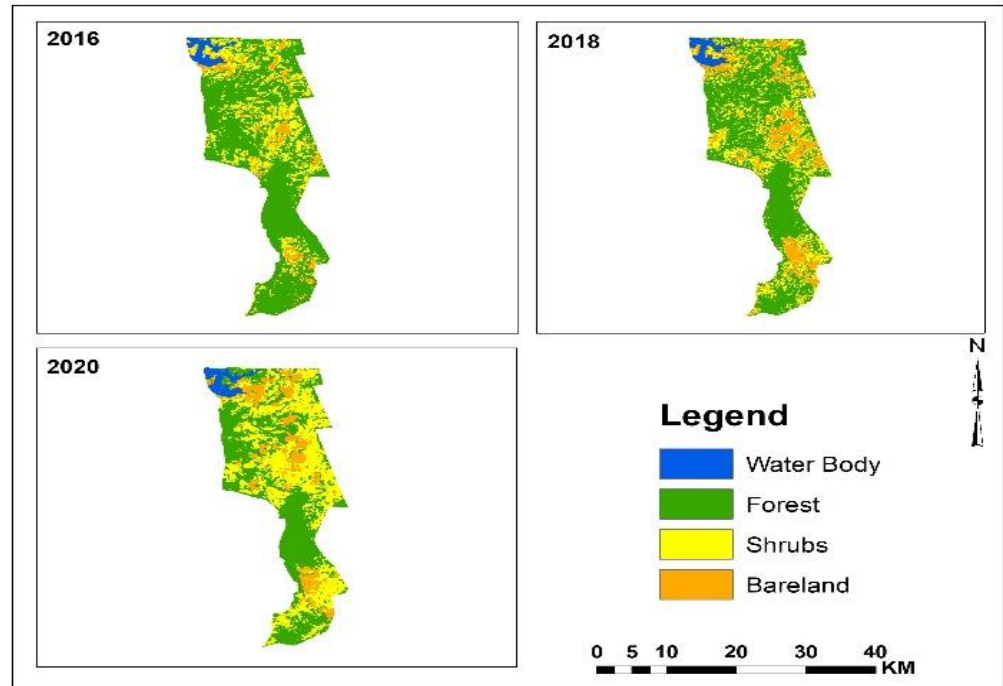

Fig 2: Land use Land cover of Akure Forest Reserve in 2016, 2018 and 2020.

Table 3: Land use Land cover dynamics and its percentages between 2016 and 2020.

\begin{tabular}{lllllll}
\hline & $\mathbf{2 0 1 6}$ & & $\mathbf{2 0 1 8}$ & & $\mathbf{2 0 2 0}$ & \\
\hline LULC & Area $(\mathrm{Ha})$ & $\%$ & Area $(\mathrm{Ha})$ & $\%$ & Area $(\mathrm{Ha})$ & $\%$ \\
Water Body & 187.29 & 3 & 184.68 & 2 & 178.23 & 3 \\
Forest & 4344.57 & 66 & 3769.38 & 57 & 2971.71 & 45 \\
Shrubs & 1472.13 & 22 & 1478.79 & 23 & 2533.05 & 38 \\
Bare land & 578.16 & 9 & 1149.3 & 17 & 899.34 & 14 \\
\hline
\end{tabular}




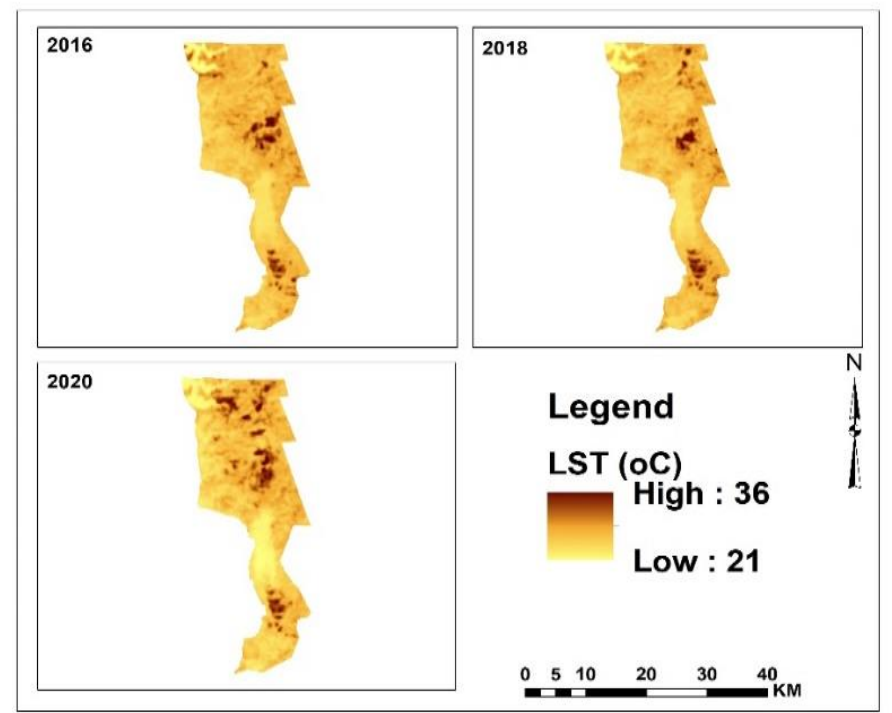

Fig 3: Land Surface Temperature (LST) for 2016, 2018 and 2020

\begin{tabular}{|c|c|c|c|c|c|c|c|}
\hline \multirow{2}{*}{\multicolumn{2}{|c|}{$\begin{array}{r}35.00 \\
30.00 \\
25.00 \\
20.00 \\
15.00 \\
10.00 \\
5.00 \\
0.00\end{array}$}} & \multirow{2}{*}{\multicolumn{2}{|c|}{ Std. }} & \multirow{2}{*}{\multicolumn{2}{|c|}{$\begin{array}{l}\text { Std. } \\
\text { Dev. }\end{array}$}} & $\pi$ & \multirow{2}{*}{$\begin{array}{l}\text { Std. } \\
\text { Dev. }\end{array}$} \\
\hline & & & & & & Mean & \\
\hline & Water body & 22.28 & 0.89 & 23.28 & 0.53 & 22.58 & 0.50 \\
\hline & Forest & 24.90 & 1.01 & 26.28 & 0.99 & 23.90 & 0.89 \\
\hline & Shrubs & 26.52 & 1.40 & 27.32 & 0.95 & 25.29 & 0.88 \\
\hline & Bare land & 27.70 & 1.99 & 28.99 & 2.04 & 27.14 & 1.57 \\
\hline
\end{tabular}

Fig 4: Mean LST and Standard deviation across LULC of 2016, 2018 and 2020

The noticed changes in the forest ecosystem might not be unconnected to the high rate of deforestation in Nigeria. It can also be opined that governments' failure to protect forest reserves, has also given illegal felling of trees a big boost in recent times.

Land surface temperature across LULC: The Land surface temperature (LST) of 2016, 2018 and 2020 are shown in Figure 7. They revealed that the distribution of temperatures across the forest landscape is quite distinctive according to the land cover types. The highest mean LST was restricted to the bare land areas of the forest. In 2016, 2018 and 2020 the mean LST of bare land were $27.70{ }^{\circ} \mathrm{C}, 28.99{ }^{\circ} \mathrm{C}$ and $27.14{ }^{\circ} \mathrm{C}$ respectively (Figure 8 ). Forest on the other hand, has an average LST of $24.90^{\circ} \mathrm{C}, 26.28^{\circ} \mathrm{C}$ and $23.90^{\circ} \mathrm{C}$ for 2016, 2018 and 2020 respectively. Water body has the least mean LST with $22.28^{\circ} \mathrm{C}$, in $2016,23.28^{\circ} \mathrm{C}$ in 2018 and $22.58{ }^{\circ} \mathrm{C}$ in 2020 . The results in Figure 8 further explained that bare land has the highest thermal signal compared to other land covers. While lower land surface temperatures are evident in places with vegetation cover and water body Orimoloye et al., (2018b). Of scientific interest, is the mean LST of forest $\left(26.28^{\circ} \mathrm{C}\right)$ in 2018 which is higher than that of $2020\left(23.90^{\circ} \mathrm{C}\right)$. This can be attributed to the increase of forest undergrowth within the two years interval. Relationships between LST and selected vegetation indices in 2016, 2018 and 2020: It is very difficult to extensively calculate the multi-scale and multi-impact 
nature of vegetation stress. Hence the combination of different parameters or spectral indices in a single analysis is required (Hayes et al., 2012). To assess the relationship between land surface temperature (LST) and the four vegetation indices listed in Table 2, regression analysis, using image to image scatterplots were carried out to ascertain the strength of the relationships between land surface temperature (LST) and the selected vegetation indices (NDVI, NDWI, VCI and VHI). The scatterplot algorithm in SAGA GIS software was used to carry out the regression analysis. The results in Figures 8, 9 and 10 revealed that the relationships between LST and NDVI of 2016, 2018 and 2020 are $3.53 \%, 2.90 \%$ and $11.93 \%$ respectively. The NDVI is widely used to estimate the density and health of vegetation. Because of the close relationship between vegetation vigor and available soil moisture, it has been used to monitor forest stress.

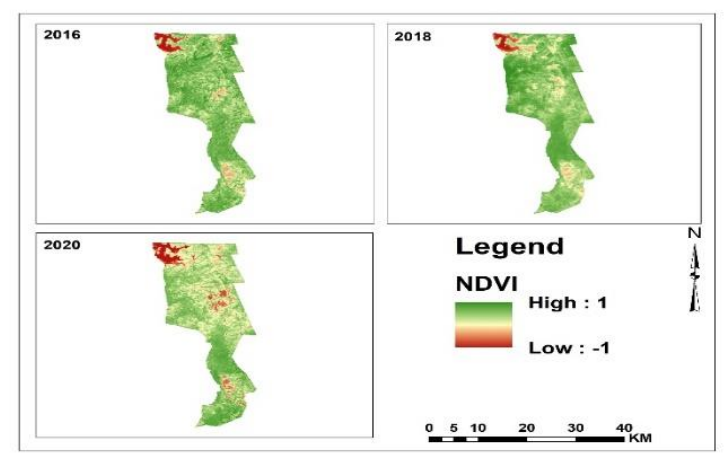

Fig 5: NDVI of Akure Forest Reserve for 2016, 2018 and 2020

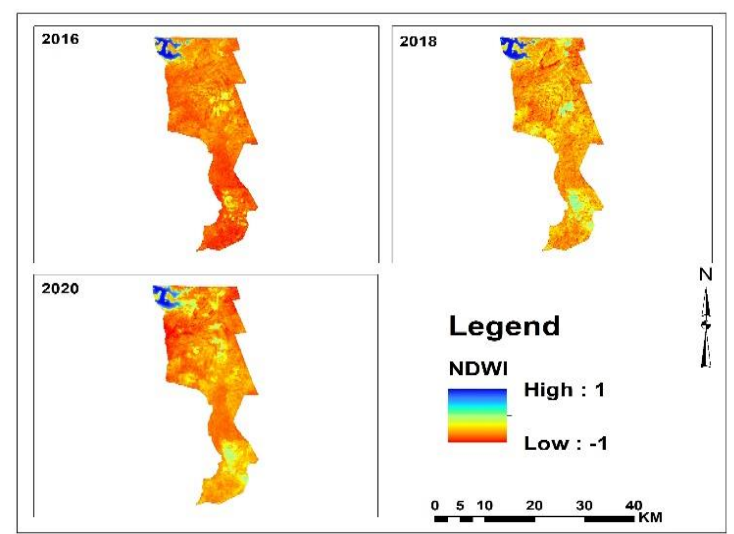

Fig 6: NDWI of Akure Forest Reserve for 2016, 2018 and 2020.

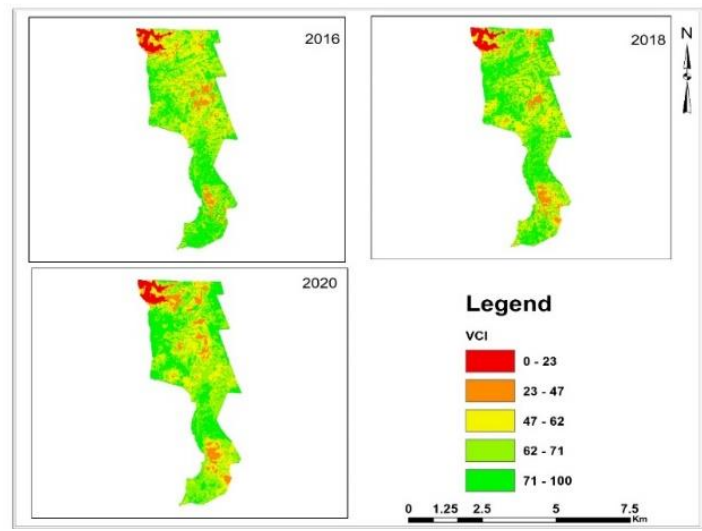

Fig 7: Vegetation Condition Index (VCI) for 2016, 2018 and 2020.

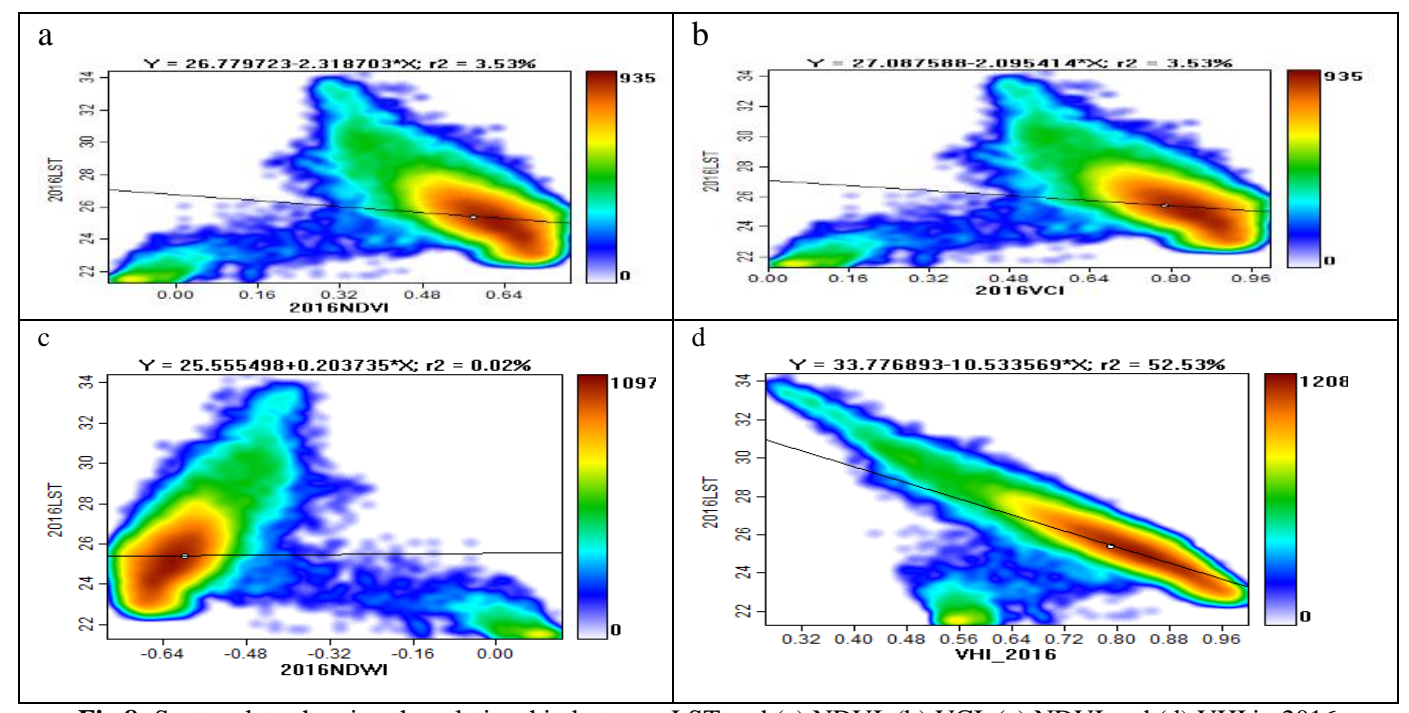

Fig 8: Scatterplots showing the relationship between LST and (a) NDVI, (b) VCI, (c) NDVI and (d) VHI in 2016 


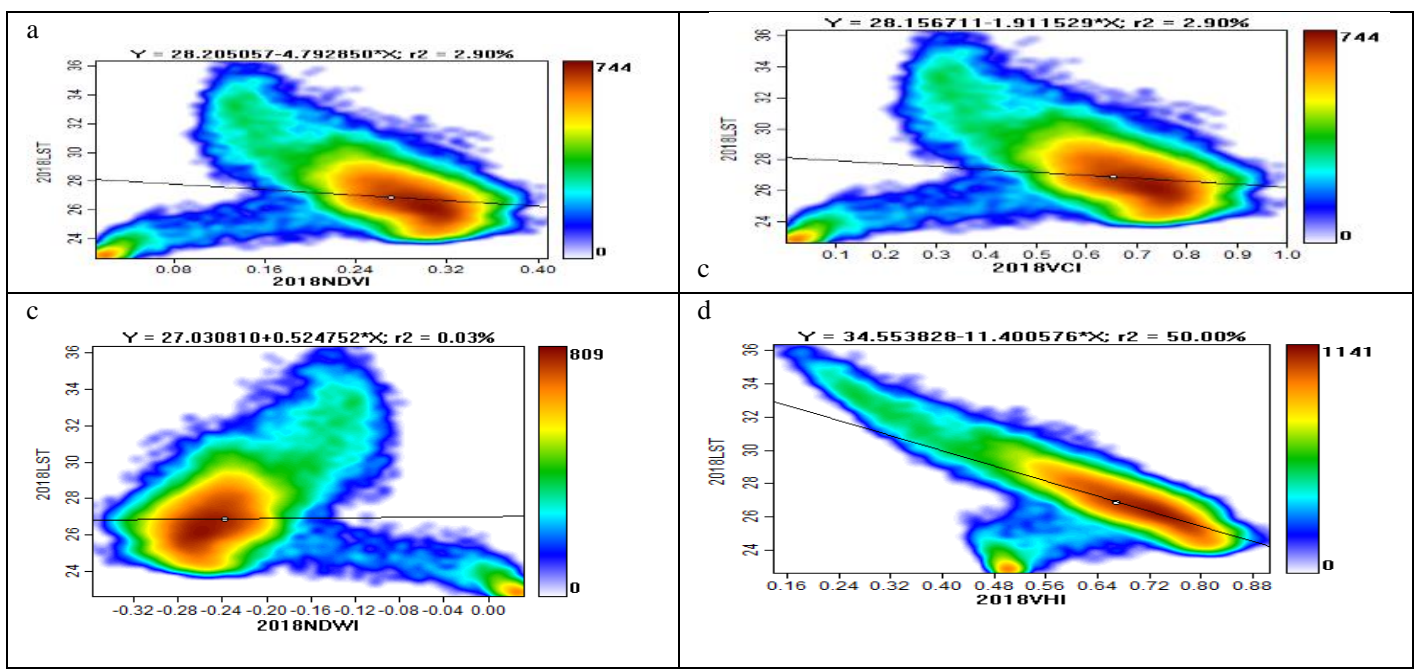

Fig 9: Scatterplots showing the relationship between LST and (a) NDVI, (b) VCI, (c) NDVI and (d) VHI in 2018

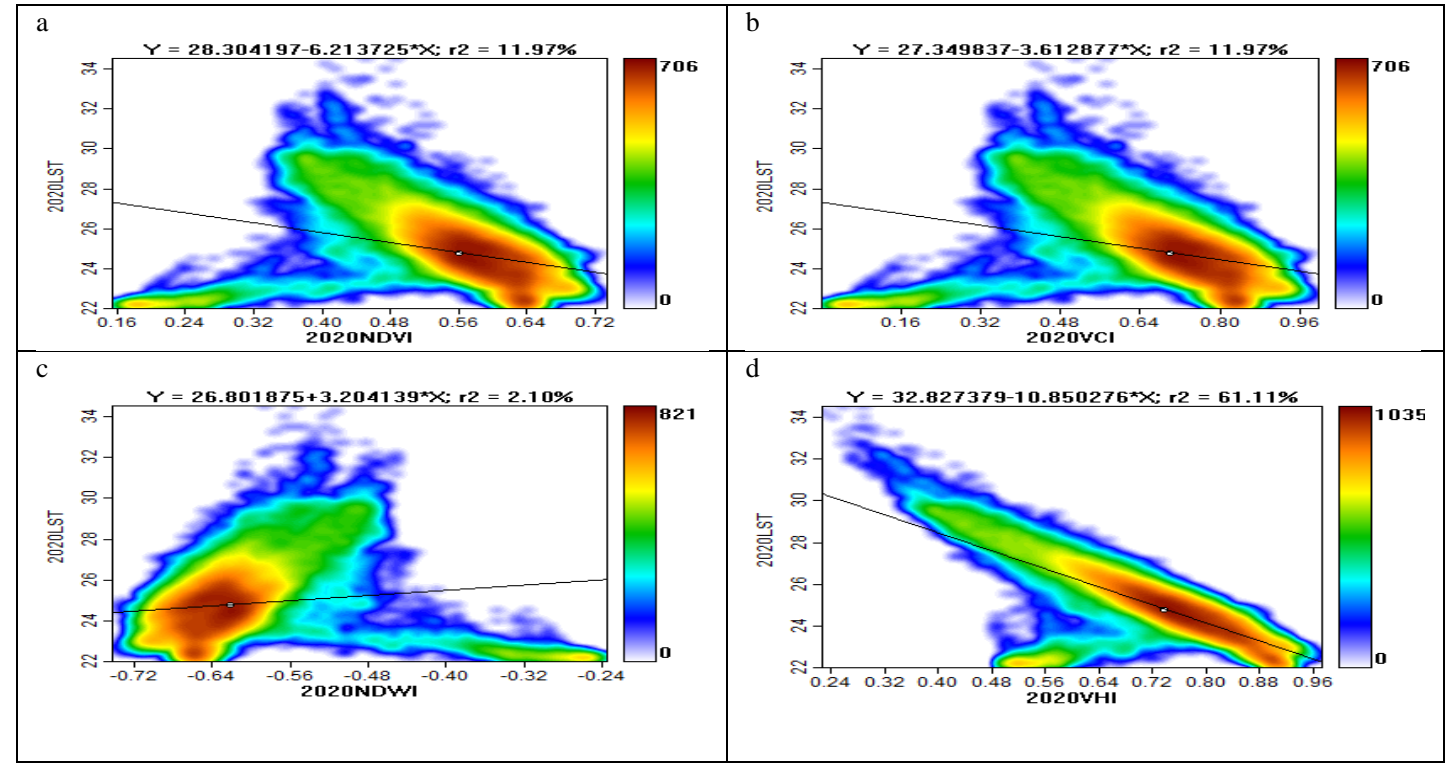

Fig 10: Scatterplots showing the relationship between LST and (a) NDVI, (b) VCI, (c) NDVI and (d) VHI in 2016

The correlation analysis between LST and VCI of 2016, 2018 and 2020 are very much similar to that of NDVI. This is because there is always a negative relationship between LST and vegetation. These results are traceable to the effects of vegetation in reducing thermal signals within the forest ecosystem as corroborated by Subhanil and Himanshu (2020). Though, the relationship between LST and VHI in 2016, 2018 and 2020 are inverse, the $\mathrm{R}^{2}(52.53 \%, 50 \%$ and $61.11 \%$ ) are averagely high.

Forest stress assessment using Vegetation Health Index (VHI): The result in Figure 11 shows the spatial distribution of vegetation health index for 2016, 2018 and 2020. It must be stated that caution needs to be taken whenever spectral indices are used in delineating forest stress, forest health and drought. This is because oftentimes, changes in land use land cover, consequent upon deforestation, forest fire and agroforestry practices could be confused with areas experiencing forest stress. It therefore behooves on researchers to spectrally delineate cells that are affected with vegetation cover from pixels that are exposed to thermal induced stress. (Gulácsi and Kovács, 2018). 


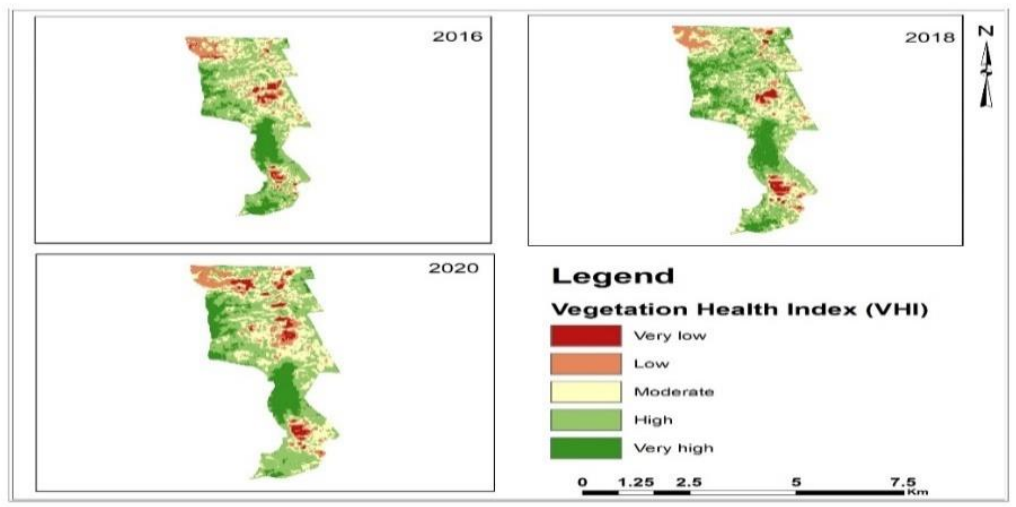

Fig 11: Spatial distribution of VHI in the study area for 2016, 2018 and 2020.

The 'Low', 'Very low' and 'Moderate' classes of the VHI (Figure 11) are very much in alignment with 'Water body', 'Bare land' and 'Shrubs' classes of the LULC distribution maps of all the years under consideration (Figure 2). Therefore, by extension, these classes must be isolated from the VHI analysis because they are not stress-induced. It suffices therefore to restrict variability in forest stress assessment to 'High' and 'Very high' classes of VHI. In 2016, about 2,808.89 ha of Akure forest reserve had 'High' vegetation health index while 'Very high' VHI was 1,075.59 ha (Figure 12). But in 2018, the healthiest part of the forest (Very high) occupied a total area of about $1,180.62$ ha as against $1,075.59$ ha in 2016. This shows an increase of about 105.03 ha (Figure 13).

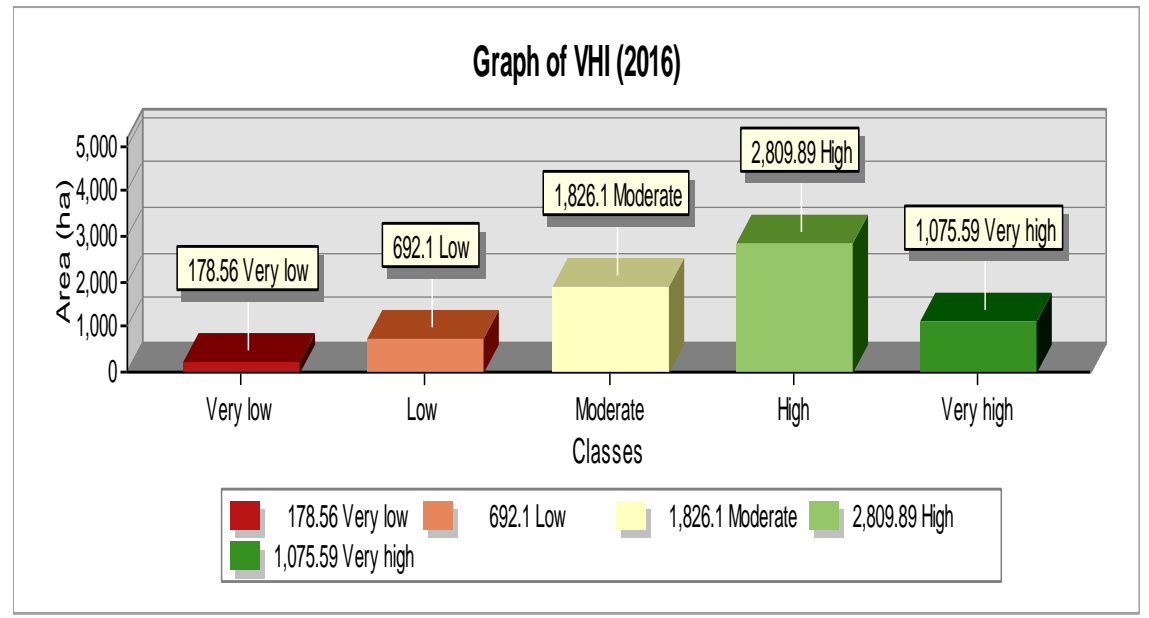

Fig 12: Graphical representation of VHI statistics of the study area in 2016.

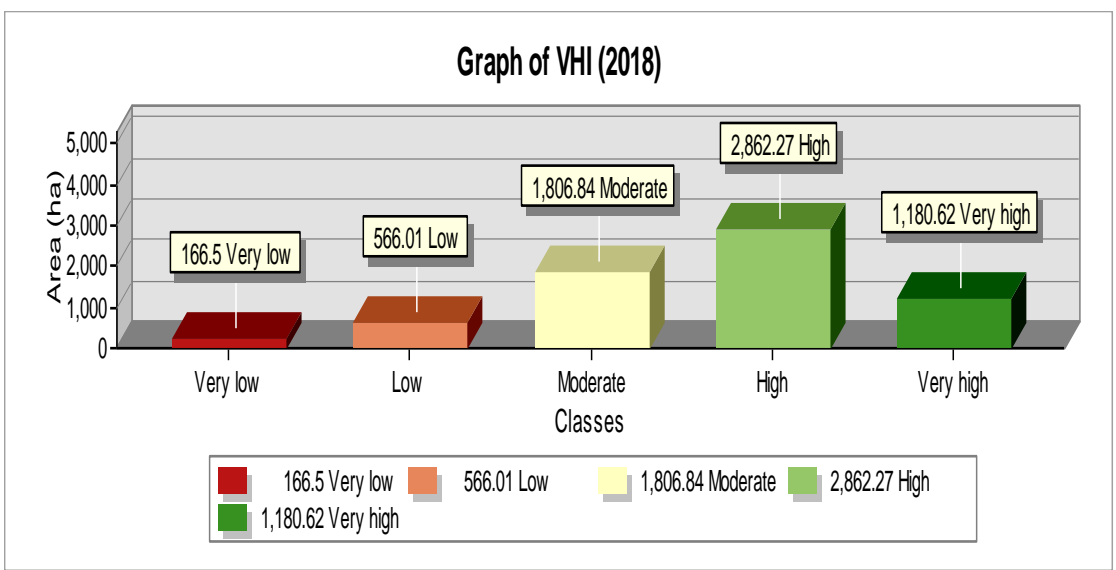

Fig 13: Graphical representation of VHI statistics of the study area in 2018. 


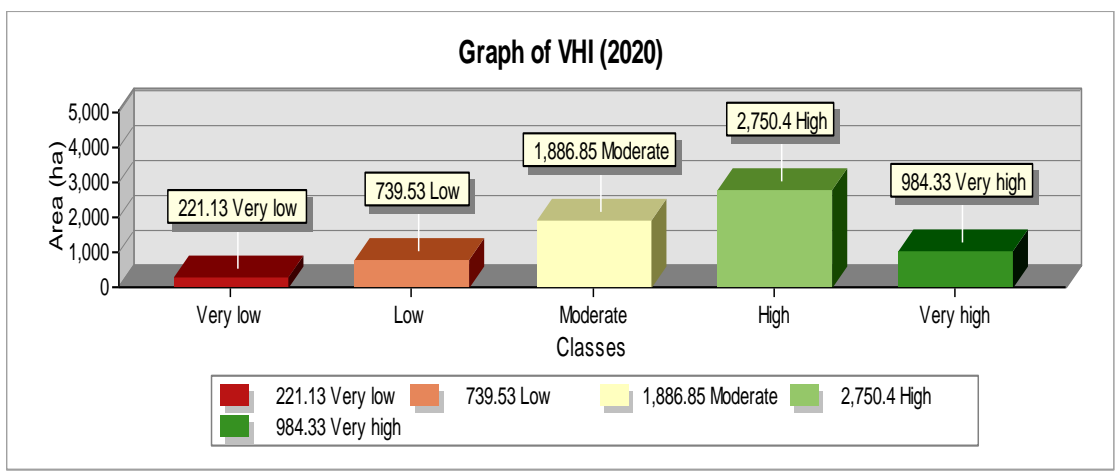

Fig 14: Graphical representation of VHI statistics of the study area in 2020.

Table 4: Mean LST and standard deviation of VHI

\begin{tabular}{|c|c|c|c|c|c|c|}
\hline & 2016 & & 2018 & & 2020 & \\
\hline VHI & $\begin{array}{l}\text { Mean } \\
\text { LST }\left({ }^{\circ} \mathrm{C}\right)\end{array}$ & $\begin{array}{l}\text { STD } \\
\left({ }^{\circ} \mathrm{C}\right)\end{array}$ & $\begin{array}{l}\text { Mean } \\
\text { LST }\left({ }^{\circ} \mathrm{C}\right)\end{array}$ & $\begin{array}{l}\text { STD } \\
\left({ }^{\circ} \mathrm{C}\right)\end{array}$ & $\begin{array}{l}\text { Mean } \\
\text { LST }\left({ }^{\circ} \mathrm{C}\right)\end{array}$ & $\begin{array}{l}\text { STD } \\
\left({ }^{\circ} \mathrm{C}\right)\end{array}$ \\
\hline Very low & 30.52 & 1.81 & 32.64 & 1.39 & 29.14 & 1.01 \\
\hline Low & 26.42 & 2.63 & 27.46 & 3.09 & 25.89 & 2.15 \\
\hline Moderate & 26.20 & 0.69 & 27.76 & 0.87 & 25.48 & 0.68 \\
\hline High & 25.04 & 0.57 & 26.56 & 0.67 & 24.36 & 0.56 \\
\hline Very high & 23.68 & 0.51 & 25.37 & 0.64 & 23.01 & 0.54 \\
\hline
\end{tabular}

It is most likely that the difference in hectares must have transitioned to other VHI classes. There was a reduction in the "Very high" class of VHI from 1180.62 ha in 2018 to 984.33 ha in year 2020. There was also a slight downward trend in the "High" category of VHI from 2862.27 ha in 2018 to 2750.4 ha in 2020 (Figure 14). The mean LST across the VHI classes as shown in Table 4, reveals that mean temperatures were highest in 2018 than 2016 and 2020. For instance, in 2016, the mean LST of the least stressed part of the forest reserve (very high) was $23.68^{\circ} \mathrm{C}$.

In year 2018, the mean temperature increased from $23.68{ }^{\circ} \mathrm{C}$ in 2016 to $25.37^{\circ} \mathrm{C}$ and reduced to $23.01{ }^{\circ} \mathrm{C}$ in 2020. The least stressed class of the forest occupied a total area of 1075.59 ha in 2016. But this increased to 1180.62 ha in 2018 and reduced to 984.33 ha. One would have expected that, with high mean LST in 2018, there ought to have been a slight reduction in the total area occupied by the least stressed part of the forest. With mean temperature dropping to $23.01{ }^{\circ} \mathrm{C}$ in 2020 , increase in the least stressed part of the forest should have been higher. It suffices therefore to infer that temperature variability is not a strong determinant for the stress or health of Akure forest reserve. This might be as a result of the short period of the study (2016 to 2020).

Conclusion: The results showed that NDVI and other related vegetation indices have negative correlation with LST, while bare land areas have positive relationship of LST between 2016 and 2020. Though, all the spectral indices could be used individually to explain the biophysical characteristics. The study revealed that temperature variability did not significantly account for the stress status of the forest. It is therefore recommended that a longer period of time should be put into consideration, with in-situ data for validation, during subsequent studies.

\section{REFERENCES}

Adejoba, O; Kleine M; Taboada, T (2014). Reducing deforestation and forest degradation and enhancing environmental services from Forests (REDDES), with support from the International Tropical Timber Organization (ITTO), IUFROSPDC and FORNESSA, Akure, Ondo, Nigeria.

Adhyani NL et al (2017) IOP Conf. Ser.: Earth Environ. Sci.

Boschetti, M; Nutini, F; Brivio, PA; Bartholomé, E; Stroppiana, D; Hoscilo, A (2013). Identification of environmental anomaly hot spots in West Africa from time series of NDVI and rainfall. ISPRS J. Photogrammetry Remote Sens. 78, 2640

Chaves, MM; Maroco, JP; Pereira, JS (2003). Understanding plant responses to drought from genes to the whole plant. Funct. Plant biol. 30, 239-264.

Domingo, C; Pons, X; Crist_obal, J; Ninyerola, M; Wardlow, B (2015). Integration of Climate Time Series and MODIS Data as an Analysis Tool for forest Drought Detection. Research and SciencePolicy Interfacing, Drought: 97. 
Gbiri IA; Nathaniel OA (2019). Analysis of Pattern and Extent of Deforestation in Akure Forest Reserve, Ondo State, Nigeria. Journal of Environmental Geography 12 (1-2):1-11

Gulácsi A; Kovács F (2018). Drought monitoring of forest vegetation using MODIS-based normalized difference drought index in Hungary. Hungarian Geographical Bulletin 67 (1): 29-42

Hayes, MJ; Svoboda, MD; Wardlow, B; Anderson, MC; Kogan, F (2012a). Drought monitoring: Historical and current perspectives. Remote Sensing for Drought: Innovative Monitoring Approaches. Boca Raton, FL: CRC Press, Taylor and Francis Group: 1-19

Hayes MJ; Svoboda MD; Wall N; Widhalm M (2011b) "The Lincoln declaration on drought indices: Universal Meteorological Drought index recommended." Bull. Am. Meteo. Soc. 92: 485488.

Kogan (1995). Application of vegetation index and brightness temperature for drought detection. Adv. Space Res. 15 (11):91-100

Masih, I; Maskey, S; Mussá, F; Trambauer, P (2014). A review of droughts on the African continent: a geospatial and long-term perspective. Hydrology and Earth System Sciences 18, 3635-3649

NiMET, 2016. Nigeria Climate Review Bulletin 2007. Nigerian Meteorological Agency. Available online at: https://nimet.gov.ng/contact

Orimoloye, IR; Kalumba, AM; Mazinyo, SP; Werner, N (2018). Geospatial analysis of wetland dynamics: wetland depletion and biodiversity conservation of Isimangaliso Wetland, South Africa. J. King Saud Univ. Sci. In press.

Orimoloye, IR; Mazinyo, SP; Nel, W; Kalumba, AM (2018). Spatiotemporal monitoring of land surface temperature and estimated radiation using remote sensing: human health implications for East London, South Africa. Environ. Earth Sci. 77 (3), 77

Quiring, SM; Ganesh, S (2010). Evaluating the utility of the Vegetation Condition Index (VCI) for monitoring meteorological drought in Texas. Agric. For. Meteorol. 150 (3):330-339
Rhee, J; Im, J; Park, S (2014). Regional drought monitoring based on multi- sensor remote sensing. In: EGU General Assembly Conference, Vol. 16, EGU2014-9609

Stocker, TF; Dahe, Q; Plattner, GK (2013). The Physical Science Basis. Working Group I Contribution to the Fifth Assessment Report of the Intergovernmental Panel on Climate Change; Summary for Policymakers (IPCC, 2013); IPCC: Bern, Switzerland, 2013; 1-33

Subhanil, G; Himanshu, G (2020). An assessment on the relation between land surface temperature and normalized difference vegetation index. Environ. Develop. Sustainability. 23: 1944-1963

Swain, S; Wardlow, BD; Narumalani, S; Tadesse, T; Callahan, K (2011). Assessment of vegetation response to drought in Nebraska using TerraMODIS land surface temperature and normalized difference vegetation index. GIScience Rem. Sens. 48 (3): 432-455

Tosunoglu, F; Can, I (2016). "Application of copulas for regional bivariate frequency analysis of meteorological droughts in Turkey," Natural Hazards: J. Inter. Soc. Prevent. Mitigate. Nat. Haze. 82(3): 1457-1477

World Meteorological Organization (2012). Standardized Precipitation Index User Guide (Svoboda M; Hayes M; Wood D). (WMO-No. 1090), Geneva

Yang, J; Weisberg, PJ; Bristow, NA (2012). Landsat remote sensing approaches for monitoring longterm tree cover dynamics in semi-arid woodlands: comparison of vegetation indices and spectral mixture analysis. Rem. Sens. Environ. 119, 62-71

Yengoh, GT; Dent, D; Olsson, L; Tengberg, AE; Tucker III, CJ (2015). Use of the Normalized Difference Vegetation Index (NDVI) to Assess Land Degradation at Multiple Scales: Current Status, Future Trends, and Practical Considerations. Springer Intl Pub. Vol 1, XX, 110.

Zhang, L; Jiao, W; Zhang, H; Huang, C; Tong, Q (2017). Studying drought phenomena in the Continental United States in 2011 and 2012 using various drought indices. Rem. Sens. Environ. 190, 96-106 